\title{
The Influence of Culture on Financial Reporting Quality in Malaysia
}

\author{
Hafiza Aishah Hashim ${ }^{1}$ \\ ${ }^{1}$ Faculty of Management and Economics, Universiti Malaysia Terengganu, Terengganu, Malaysia \\ Correspondence: Hafiza Aishah Hashim, Faculty of Management and Economics, Universiti Malaysia \\ Terengganu, 21030 Kuala Terengganu, Terengganu, Malaysia. Tel: 60-9-668-3427. E-mail: \\ hafizaaishah@umt.edu.my
}

Received: July 2, 2012 Accepted: July 24, 2012 Online Published: October 19, 2012

doi:10.5539/ass.v8n13p192 URL: http://dx.doi.org/10.5539/ass.v8n13p192

\begin{abstract}
The purpose of this study is to investigate whether financial reporting quality relates to national culture. Besides the conventional corporate governance mechanism of the board of directors and substitute corporate governance mechanism of ownership structure, culture and religious traditions have been considered as having an important influence on corporate governance systems employed in any one country. Malaysia is a multiethnic society with Chinese and Malays dominating economics and politics in Malaysia. Ethnicity acts as a suitable surrogate for culture in Malaysia, which has a multiracial society, each section of which still maintains its own unique ethnic identity and values. This study uses a discretionary component of the accrual quality model as a measure for financial reporting quality to examine the association between ethnicity and financial reporting quality. This study finds no significant relationship between the race of chairman and race of CEO and accrual quality. Interestingly, this study reports higher financial reporting quality associated with firms dominated by Malay directors. The finding of this study suggests that the quality of financial reporting cannot be culturally free and is impacted largely by government policy. This study offers an alternative explanation on the association between governance and financial reporting quality by examining the role of ethnicity that explicates the unique institutional context of an Asian country.
\end{abstract}

Keywords: culture, ethnicity, corporate governance, accrual quality

\section{Introduction}

Politics, cultural and historical roots are always important factors to be considered when discussing the corporate practices of different countries around the world (Cornelius, 2005). Based on the cross-cultural work of Hofstede (1980; 1983), Gray (1988) proposes a framework linking Hofstede's cultural values with the development of accounting attitudes and systems internationally. He posits that the accounting values derived from Hofstede's (1980) cultural values influence the development of countries financial reporting systems. A number of studies have utilized the Hofstede-Gray framework and provide evidence of the influence of culture on financial reporting systems such as international audit practice (Cohen, Pant \& Shar, 1993), the relevance of an accounting system (Baydoun \& Willett, 1995), financial performance (Flamholtz, 2001), firm-level disclosures (Hope, 2003), choices of accounting accruals (Guan, Pourjalali, Sengupta, \& Teruya, 2005) as well as the application of financial reporting rules (Tsakumis, 2007).

Historical factors and cultural characteristics appear to have a significant impact on business ethics, corporate practices and the behaviour of board members in Malaysian firms that have evolved from a traditional family business into public listed corporations (Ow-Yong \& Guan, 2000). Although there are few proxies for culture, ethnicity acts as a suitable surrogate for culture in Malaysia, which has a multiracial society, each section of which still maintains its own unique ethnic identity and values (Haniffa \& Cooke, 2005; Salleh, Stewart, \& Manson, 2006). In Malaysia, Malays and Chinese play a dominant role in politics and economics, regulators being predominantly Malays and businesses mainly owned by the Chinese (Abdullah, 2006). While Malays form the majority ethnic group, the Chinese have always been the most economically prominent in Malaysia (Mamman, 2002).

A study by Mansor and Kennedy (2000) on the Malaysian culture and the leadership of organisations notes that Malay cultural values have developed from a history of communal living and cooperation. The Malays are often cited as being high on collectivism and the Malay leaders are expected to place their own interests ahead of the 
group. Although the Malays are the majority ethnic group in Malaysia, the Malays have been left out of the economic mainstream during the colonial period (Mamman, 2002). In that sense, the Malays are not found to have the same strong history of entrepreneurial involvement as other ethnic groups in Malaysia, which translates into a lower level of performance orientation in their leadership role (Mansor \& Kennedy, 2000).

In contrast, the Chinese leaders show remarkably high entrepreneurship with good self-discipline and strategic thinking (Wah, 2002). The Chinese leaders apply good strategies in leading organisations and successfully lead and grow their family-managed businesses into professionally-managed organisations (Wah, 2002). In many East Asian countries, Chinese family groups have played a dominant role in business (Ball, Robin, \& Wu, 2003). As reported by Weidenbaum and Hughes (1996) cited from Ball et al. (2003), the total market capitalization of the 500 largest public companies in Asia exceeded $\$ 400$ billion, with the highest in Hong Kong ( $\$ 155$ billion), followed by Malaysia ( $\$ 55$ billion), Singapore ( $\$ 42$ billion) and Thailand ( $\$ 35$ billion). Though often cited as a minority, the economic power of ethnic minority Chinese is more than half of the native major population and has been argued as a source of racial tension in many Southeast Asian countries including Indonesia, Thailand and Malaysia (Ball et al., 2003). As the directors of Malaysian corporations come from different ethnic backgrounds, examination of their influence over the quality of financial reporting quality will provide a new direction on the sociological aspects of corporate governance research.

Historically, Malaysia was a former British colony. Hence, the development of company law in Malaysia closely follows the pattern of the United Kingdom's company legislation. The Malaysian accounting and auditing standards replicate those found in the UK as well as other commonwealth countries such as Australia and New Zealand (Gul, 2006). Although there are broad similarities with regards to accounting and regulatory environments with the US and the UK, the Malaysian corporate sector operates in a different institutional environment, which is characterised by the existence of politically favoured corporations (Gul, 2006). The government intervention, partly in response to ethnic rioting in 1969, in the form of the New Economic Policy (NEP) in 1970, intended to eliminate the identification of race with economic functions (Tam \& Tan, 2007). The NEP is aimed at achieving 30 percent Bumiputera (refers to Malaysian for Malays and other indigenous ethnic groups) ownership of the corporate sector by 1990. This resulted in an affirmative action in favour of the Bumiputera (Gomez \& Jomo, 1999). Since then, the Bumiputera have been given priority of various concessions including business contracts, access to capital as well as other subsidies (Johnson \& Mitton, 2003). Various state agencies are also established to meet the NEP objectives (Chu \& Cheah, 2006). Though Bumiputera ownership has grown tremendously from 2.4 percent in 1970 to 18.9 percent in 2004, the ownership still fell short of the initial target of 30 percent. Meanwhile, Chinese equity ownership has increased to more than double that of the Bumiputera (Table 1).

Table 1. Ownership of share capital ${ }^{1}$ (at par value) of limited companies, 1970, 1995, 2000 and 2004

\begin{tabular}{lrrrr}
\hline Ownership Group & 1970 & 1995 & 2000 & 2004 \\
\hline Bumiputera $_{\text {Individuals \& Institutions }}{ }^{2}$ & 2.4 & 20.6 & 18.9 & 18.9 \\
Trust Agencies $^{3}$ & 1.6 & 18.8 & 17.2 & 17.2 \\
Non-Bumiputera $^{\text {Chinese }}$ & 0.8 & 2.0 & 1.7 & 1.7 \\
Indians & 28.3 & 43.4 & 41.3 & 40.6 \\
Others & 27.2 & 40.9 & 38.9 & 39.0 \\
Nominee Companies & 1.1 & 1.5 & 1.5 & 1.2 \\
Foreigners & - & 1.0 & 0.9 & 0.4 \\
\hline Source: Second
\end{tabular}

Sources: Second Malaysian Plan, 1971-1975; Seventh Malaysian Plan, 1996-2000; Eighth Malaysian Plan, 2001-2005; Ninth Malaysian Plan, 2006-2010.

Notes: ${ }^{1}$ Excludes shares held by Federal and State Governments.

${ }^{2}$ Refers to shares held through institutions channeling Bumiputera funds such as the Permodalan Nasional Berhad (PNB) unit trust schemes, Amanah Saham MARA, Lembaga Tabung Haji, Lembaga Tabung Angkatan Tentera and Koperasi Polis.

${ }^{3}$ Refers to shares held through trusts agencies such as PNB, Perbadanan Usahawan Nasional Berhad, Perbadanan Nasional Berhad, Majlis Amanah Rakyat (MARA), Bank Pembangunan Malaysia Berhad and State Economic Development Corporations. 
As a consequence of government favouritism towards Bumiputera, Chinese companies were starting to appoint influential Bumiputera by the early 1990s to enjoy the benefit from the government (Mamman, 2003). Nevertheless, post-NEP reveals that division in economic activities among ethnicities remains and the income distribution is still uneven between ethnic groups, with Bumiputera mostly in the lower occupational categories (Tam \& Tan, 2007). Mamman (2003) finds that the ethnicity of managers influences their attitudes to the role of the government in Malaysia. While Malay managers are more likely to support government policies, Chinese and Indian managers are more likely to support laissez-faire economic policies. Ball et al. (2003) argue that intervention from the government creates political costs for firms-controlled by minority ethnic Chinese that provides incentives for them to avoid reporting high profits.

The capabilities of Bumiputera-controlled firms and politically connected firms are often cited for poor performance and poor corporate governance practice in Malaysia (Johnson \& Mitton, 2003; Gul, 2006; Yatim, Kent, \& Clarkson, 2006). In the early phase of the Asian 1997 financial crisis, evidence suggests that politically connected firms had poorer stock returns (Johnson \& Mitton, 2003) and higher audit fees (Gul, 2006) compared to non-politically connected firms. Further analysis by Gul (2006) documents a positive significant association between firms with Bumiputera ownership and audit fees. His findings suggest that Bumiputera firms are perceived to have greater agency costs than non-Bumiputera firms (i.e. Chinese firms).

Nonetheless, studies by Haniffa and Cooke (2002) and Haniffa and Cooke (2005) suggest that Bumiputera firms use voluntary disclosures as a legitimating strategy to please the various interest groups, including ensuring a continued influential voice at both governmental and institutional levels. Haniffa and Cooke (2002) and Haniffa and Cooke (2005) find that Malay dominated boards are positively related to voluntary disclosure and corporate social disclosure in Malaysia. Haniffa and Cooke (2005, p.417) suggest that 'board dominated by Malays adopt a reactive legitimating strategy to change perceptions and divert the attention of its various stakeholders away from the close-relationship they enjoy with government by increasing social responsibility disclosures'. Supporting these studies, Yatim et al. (2006) document evidence that Bumiputera-controlled firms practice favourable corporate governance practices relative to their non-Bumiputera counterparts. Although contradictory with earlier findings by Johnson and Mitton (2003), their findings suggest that corporate governance practices have changed in Malaysia following the corporate governance reforms in 2001.

Ball et al. (2003) argue that firms controlled by ethnic minorities are more likely to encounter political costs from reporting high profits and as a consequence, minority ethnic Chinese have political incentives to avoid reporting large profits. Yet, the empirical evidence is lacking. Abdul Rahman and Mohamed Ali (2006) do test the relationship between ethnicity and earnings management but do not find any significant evidence. It seems that there have been no empirical studies published on the relationship between ethnicity and accrual quality (to the best knowledge of the researcher). Though prior literature suggests the importance of addressing the different cultural characteristics of the financial reporting process (Gray, 1988; Flamholtz, 2001; Ball et al., 2003; Hope, 2003), there is no study yet that has addressed this issue by linking the influence of ethnicity to accounting accrual quality. Based on the above discussion, the study proposes the following testable hypothesis:

$\mathrm{H}_{1}$ : There is an association between race of the chairman and accrual quality.

$\mathrm{H}_{2}$ : There is an association between race of the $\mathrm{CEO}$ and accrual quality.

$\mathrm{H}_{3}$ : There is an association between racial composition and accrual quality.

\section{Method}

\subsection{Sample Selection}

The initial sample of the study consists of all companies that were listed on the Main Board of Bursa Malaysia for the period 1998 to 2006. At the end of the year 2006, there were 649 financial and non-financial companies listed on the Main Board. Due to different statutory requirements, all banks, insurance and unit trusts companies as well as utility companies were excluded from the population of interest, reducing the sample size to 592 non-financial companies.

For a sample of three years period, nine years complete accounting data, $t=1998-2006$ is required to estimate accrual quality. For that reason, the number of data observations is further reduced to 424 non-financial companies with complete data for current assets, current liabilities, cash, change in debt in current liabilities, cash flow from operations, revenues and property, plant and equipment. A firm is included in the year $t$ sample if data is available for year's $t-4$ to $t$. Any firms that were de-listed within years 1998 to 2005 were also excluded from the population of interest due to incomplete data. As consistent with prior research (Davidson, Goodwin-Stewart \& Kent, 2005; Abdul Rahman \& Mohamed Ali, 2006) industries with less than 8 firms were 
also eliminated from the analysis. Further, 139 companies were excluded as the required financial and corporate governance data was not available, resulting in a final sample of 277 companies from 2003 to 2005, giving a total of 831 firm-year observations with complete data for accrual quality and board of directors' characteristics.

\subsection{Regression Model}

The following multiple regression model was utilised to determine the extent of the influence of each of the variables in the study on the accrual quality:

$$
\begin{aligned}
& D I S C A Q=\beta_{0}+\beta_{1} R C H A I R+\beta_{2} R C E O+\beta_{3} R C O M P+\beta_{4} B I N D+\beta_{5} F A M C O N T R O L+\beta_{6} M G R L O W N S+\beta_{7} \\
& \quad B D S I Z E+\beta_{8} L N S I Z E+\beta_{9} L E V+\beta_{10} R O A+\beta_{I 1} B I G 4+\beta_{I 2} D U M+Y R O 4+\beta_{13} D U M+Y R O 5+\varepsilon
\end{aligned}
$$

The dependent variable is accrual quality $(D I S C A Q)$ measured by standard deviation of accrual quality residuals. The independent variables consist of race of chairman (RCHAIR), race of CEO (RCEO) and racial composition (RCOMP). Consistent with prior studies (Peasnell, Pope \& Young, 2000; 2005; Bedard, Chtourou \& Courteau, 2004; Jaggi, Leung \& Gul, 2009), this study includes board independence (BIND), family control on board (FAMCONTROL), managerial ownership (MGRLOWNS), board size (BDSIZE), firm size (LNSIZE), leverage $(L E V)$, return on assets $(R O A)$, audit quality $(B I G 4)$ and years dummies $\left(D U M_{-} Y R\right)$ as control variables in the regression model.

\subsection{Accrual Quality Model}

To measure financial reporting quality, this study applies Dechow and Dichev's (2002) accrual quality model (hereafter DD) that captures one aspect of the quality of accruals and earnings. This measure is based on the observation that accruals map into cash flow realizations and regardless of managerial intent, the accrual quality is affected by the measurement error in accruals. The nature of accruals that are frequently based on the assumptions and estimates create estimation errors that need to be corrected in the future.

In the DD approach, the estimated residuals from firm specific regressions of working capital accruals, on past, present, and future cash flow from operation, captures the total accruals estimation error by management and are viewed as an inverse measure of earnings quality. The DD model is measured by estimating the following regression (all variables are scaled by average assets):

$$
\Delta T C A_{j, t}=\varphi_{0, j}+\varphi_{1, j} C F O_{j, t-1}+\varphi_{2, j} C F O_{j, t}+\varphi_{3, j} C F O_{j, t+1}+v_{j, t}
$$

Where, $\triangle T C A_{j, t}$ is the firm $j$ 's total current accruals in year $t,=\left(\Delta C A_{j, t}-\triangle C L_{j, t}-\Delta C a s h_{j, t}+\triangle S T D E B T_{j, t}\right) ; \Delta C A_{j, t}$ the firm $j$ 's change in current assets between year $t-1$ and year $t$; the firm $\triangle C L_{j, t}=$ Firm $j$ 's change in current liabilities between year $t-1$ and year $t ; \Delta \operatorname{Cash}_{j, t}$ the firm $j$ 's change in cash between year $t-1$ and year $t$; $\triangle S T D E B T_{j, t}$ the firm $j$ 's change in debt in current liabilities between year $t-1$ and year $t ;$ Assets $_{j, t}$ the firm $j$ 's average total assets in year $t$ and $t-1$; and $C F O_{j, t}$ the firm $j$ 's net cash flow from operation in year $t$.

For each firm-year, equation 2 is estimated cross-sectionally for all firms (minimum 8 firms within each industry groups) using rolling 7-year windows. These estimations yield five firm- and year-specific residuals, $v_{j, t}, t=$ $t-4, \ldots t$, which form the basis for accrual metric. Accrual Quality $j, t=\sigma\left(v_{j, t}\right)$, is equal to the standard deviation of firm $j$ 's estimated residuals. Larger standard deviations of residuals correspond to poorer accrual quality and vice versa.

The original DD model does not distinguish between intentional and unintentional estimation errors. Following the modified accrual quality model of Francis, LaFond, Olsson, and Schipper (2005), this study distinguishes between accrual quality driven by economic fundamentals (innate accrual quality) and management choices (discretionary accrual quality). Prior literature on the relation between accruals and cash flows (see e.g. Penman \& Zhang, 2002; Bernard \& Skinner, 1996; Healy \& Wahlen, 1999) includes the uncertainty in a firm's environment and managerial intervention that surround the financial reporting process as important factors that need to be considered when evaluating a firm's financial reporting quality.

Francis et al. (2005) view innate factors as relatively slower to change compared with discretionary components. They use five innate factors suggested by Dechow and Dichev (2002) as affecting innate accruals quality including firm size, standard deviation of cash flow from operations, standard deviation of sales revenue, length of operating cycle and incidence of negative earnings realization. However, in the case of Malaysia, the length of the operating cycle variable is not available during the study period. Listed companies in Malaysia were only required to disclose the length of operating cycle in the annual report following the adoption of International Financial Reporting Standards (IFRS) in 2006. Similar to the prior study by Jaggi, Leung and Gul (2007), this study drops the length of operating cycle from the regression because of the data unavailability. To distinguish between innate and discretionary accruals quality, the innate components of accruals quality is regressed on the 
annual regressions of accruals quality as follows:

$$
A Q_{j, t}=\lambda_{0}+\lambda_{1} \operatorname{SIZE}_{j, t}+\lambda_{2 j} \sigma\left(C F O_{j, t}\right)+\lambda_{3} \sigma\left(S A L E S_{j, t}\right)+\lambda_{4} N E G E A R N_{j, t}+\mu_{j, t}
$$

Where, SIZE is the log of total assets; $\sigma C F O$ is the standard deviation of cash flow from operations calculated over the past seven years; $\sigma S A L E S$ is the standard deviation of sales revenue calculated over the past seven years; and $N E G E A R N$ is the number of years, out of the past seven, where firm $j$ reported NIBE $<0$. The predicted value from each regression yields an estimate of the innate portion of firm $j$ 's accrual quality in year $t$,

$$
\text { InnateA } Q_{j, t}=\lambda_{0}+\lambda_{1} \operatorname{SIZE}_{j, t}+\lambda_{2 j}\left(C F O_{j, t}\right)+\lambda_{3} \sigma\left(\operatorname{SALES}_{j, t}\right)+\lambda_{4} N E G E A R N_{j, t}
$$

The residual from equation 3 is the estimate of the discretionary component of the firm $j$ 's accrual quality in year $t, \operatorname{DiscA}_{j, t}=\mu_{j, t}$. Similar to the original DD model, larger standard deviation of residuals correspond to poorer accrual quality and vice versa. Following DeFond, Hung and Trezevant (2007), the standard deviation score of discretionary accruals is multiplied by -1 so that higher scores indicate higher financial reporting quality.

\section{Results}

\subsection{Descriptive Statistics}

\begin{tabular}{|c|c|c|c|c|c|c|c|c|}
\hline \multirow[b]{2}{*}{$\begin{array}{l}\text { Dichotomous } \\
\text { Variables }\end{array}$} & \multicolumn{2}{|c|}{$\begin{array}{c}\text { All } \\
N=831\end{array}$} & \multicolumn{2}{|c|}{$\begin{array}{c}2003 \\
N=277\end{array}$} & \multicolumn{2}{|c|}{$\begin{array}{c}2004 \\
N=277\end{array}$} & \multicolumn{2}{|c|}{$\begin{array}{c}2005 \\
N=277\end{array}$} \\
\hline & 1 & 0 & 1 & 0 & 1 & 0 & 1 & 0 \\
\hline RCHAIR & $\begin{array}{c}506 \\
(60.9 \%)\end{array}$ & $\begin{array}{c}325 \\
(39.1 \%)\end{array}$ & $\begin{array}{c}167 \\
(60.3 \%)\end{array}$ & $\begin{array}{c}110 \\
(39.7 \%)\end{array}$ & $\begin{array}{c}170 \\
(61.4 \%)\end{array}$ & $\begin{array}{c}107 \\
(38.6 \%)\end{array}$ & $\begin{array}{c}169 \\
(61 \%)\end{array}$ & $\begin{array}{c}108 \\
(39 \%)\end{array}$ \\
\hline RCEO & $\begin{array}{c}223 \\
(26.8 \%)\end{array}$ & $\begin{array}{c}608 \\
(73.2 \%)\end{array}$ & $\begin{array}{c}74 \\
(26.7 \%)\end{array}$ & $\begin{array}{c}203 \\
(73.3 \%)\end{array}$ & $\begin{array}{c}75 \\
(27.1 \%)\end{array}$ & $\begin{array}{c}202 \\
(72.9 \%)\end{array}$ & $\begin{array}{c}74 \\
(26.7 \%)\end{array}$ & $\begin{array}{c}203 \\
(73.3 \%)\end{array}$ \\
\hline RCOMP & & All & & 2003 & & 2004 & & 05 \\
\hline Mean & & 0.437 & & 0.437 & & 0.439 & & 435 \\
\hline Median & & 0.375 & & 0.375 & & 0.375 & & 375 \\
\hline Stand. Deviation & & 0.268 & & 0.271 & & 0.266 & & 268 \\
\hline Minimum & & .00 & & .00 & & .00 & & 0 \\
\hline Maximum & & 1.00 & & 1.00 & & 1.00 & & 00 \\
\hline$N$ & & 831 & & 277 & & 277 & & 77 \\
\hline
\end{tabular}

Table 2. Descriptive statistics of dichotomous variables

With respect to the ethnicity of directors, Bumiputera (Malay) directors represent an average of 43.7 percent of all directors on the board of the sample companies, indicating non-Bumiputera (Chinese) directors' domination in the board composition of Malaysian corporation. The average of 43.7 percent is higher than that reported by Salleh et al. (2006) but lower than that found by Abdul Rahman and Mohamed Ali (2006) which are 38 percent and 48 percent, respectively. The majority of companies (60.9 percent) have a Malay chairperson and Chinese CEO (73.2 percent). This is not surprising given regulators predominantly Malays and the business owned by the Chinese in Malaysia. The government policy that discriminate the business opportunity based on ethnic group that favour the Bumiputera may possibly influence the Chinese firms to appoint Malay chairperson as a legitimating strategy to ensure government support of their businesses (Mamman, 2003). 


\subsection{Regression Results}

Table 4. Regression results

White Heteroskedasticity-Consistent Standard Errors \& Covariance

\begin{tabular}{ccccc}
\hline Variable & Coefficient & Std. Error & t-Statistic & Prob. \\
C & -0.519 & 0.549 & -0.945 & 0.345 \\
RCHAIR & -0.058 & 0.078 & -0.734 & 0.463 \\
RCEO & -0.189 & 0.136 & -1.390 & 0.165 \\
RCOMP & 0.633 & 0.244 & 2.592 & $0.010^{* * *}$ \\
BIND & -0.745 & 0.486 & -1.531 & 0.126 \\
FAMCONTROL & 1.002 & 0.200 & 5.024 & $0.000^{* * *}$ \\
MGRLOWNS & -0.002 & 0.002 & -1.115 & 0.265 \\
BDSIZE & -0.018 & 0.017 & -1.079 & 0.281 \\
LNSIZE & 0.029 & 0.026 & 1.095 & 0.274 \\
LEV & 0.044 & 0.059 & 0.742 & 0.458 \\
ROA & -0.471 & 0.353 & -1.336 & 0.182 \\
BIG4 & 0.062 & 0.080 & 0.774 & 0.439 \\
DUM_YR04 & 0.003 & 0.083 & 0.037 & 0.970 \\
DUM_YR05 & 0.012 & 0.083 & 0.145 & 0.885 \\
R-squared & 0.050 & & & \\
Adjusted R-squared & 0.035 & & & \\
F-statistic & 3.296 & & & \\
Prob(F-statistic) & $0.000^{* * *}$ & & & \\
N & 831 & & &
\end{tabular}

Notes: ***Significant at 0.01 level; $* *$ Significant at 0.05 level; *Significant at 0.1 level.

DISQAQ = measured by discretionary component of accrual quality model, RCHAIR = Race of chairman measured by dichotomous variable Bumiputera and non-Bumiputera, the variable takes a value of one if the race of the Chairman is Bumiputera; otherwise it takes a value of 0, RCEO = Race of CEO measured by a dichotomous variable Bumiputera and non-Bumiputera, the variable takes a value of one if the race of the CEO is Bumiputera; otherwise it takes a value of 0 ; RCOMP = Racial composition is measured using the ratio of Bumiputera directors on the board to the total number of directors, BIND $=$ Board independence is measured by the proportion of independent non-executive directors on the board, expressed as a percentage, MGRLOWNS = Managerial ownership is measured using the percentage of shares held by the inside board members' including executive directors and non-independent non-executive directors, FAMCONTROL $=$ Family control on corporate board is measured using the ratio of family members on the board to the total number of directors, BDSIZE $=$ Board size is measured by the total number of board members, LNSIZE $=$ Size is measured by the natural $\log$ of total assets, $\mathrm{LEV}=$ Leverage is measured as the ratio of total liabilities to total assets, ROA = Return on assets is measured as ratio of net income before extraordinary items to the total assets, BIG4 = Audit quality is a dichotomous variable Big4 and non-Big4, the variable takes a value of one if the company is audited by Big4 firm; otherwise it takes a value of 0, BDSIZE = Board size is measured by the total number of board members.

Using the discretionary component of the accrual quality model as innovated by Francis et al. (2005), this study documents a positive and significant relationship between RCOMP and accrual quality for the pooled data at the 1 percent level. Neither RCHAIR nor RCEO is found to be significant. The positive result implies greater financial reporting quality when the majority of directors on the board are Malay directors. The positive and significant result between racial composition and accrual quality supports the political cost theory argument that suggests greater earnings management associated with ethnic minority Chinese. As firms controlled by ethnic minorities are more likely to encounter political costs from reporting high profits, Ball et al. (2003) suggest that minority ethnic Chinese have political incentives to avoid reporting large profits. The introduction of NEP, which 
is viewed by the Chinese investors as a direct and unfair advancement of Malay interests (Mamman, 2002), has resulted in the firms controlled by ethnic minority Chinese avoiding the reporting of large profits and thereby reducing the financial reporting quality.

Another explanation for a positive significant relationship between a board dominated by Malay directors and earnings quality in this study can be drawn from the legitimacy theory. Haniffa and Cooke (2005) suggest that the Malaysian government policy that favours the Bumiputera by discriminating business opportunity based on ethnic group, influences the Malay directors to use corporate social disclosure as a reactive legitimating strategy. As stated by Haniffa and Cooke (2005), Malay dominated boards adopt reactive legitimating strategy to divert attention from questionable business practices, cronyism, nepotism and close affiliation with the government as well as to ensure a continued influential voice at both governmental and institutional levels. Furthermore, Haniffa and Cooke (2002, p.317) suggest that the governmental focus on culture may solicit a response to secrecy from those who feel threatened'. They found less voluntary disclosure associated with boards dominated by Chinese directors.

\section{Conclusions}

Though this study does not document any significant relationship between race of chairman and race of CEO and accrual quality, the study reveals a positive and significant impact of boards dominated by Malay directors on financial reporting quality. The positive and significant result between ethnicity and financial reporting quality measured by the discretionary component of the accrual quality model in this study supports the political cost theory, which suggests that firms controlled by ethnic minorities are more likely to encounter political costs from reporting high profits (Ball et al., 2003). Nonetheless, since other variables do not document any significant relationship with accrual quality, it is possible that other factors such as politically connected firms or government linked companies could mitigate the relationship between ethnicity and financial reporting quality that have not been captured in this study and provide an interesting avenue for future research.

\section{References}

Abdul Rahman, R., \& Mohamed Ali, F. H. (2006). Board, audit committee, culture and earnings management: $\begin{array}{lllll}\text { Malaysian } & \text { evidence. }\end{array}$ http://dx.doi.org/10.1108/02686900610680549

Abdullah, S. N. (2006). Board structure and ownership in Malaysia: The case of distressed listed companies. Corporate Governance, 6(5), 582-594. http://dx.doi.org/10.1108/14720700610706072

Ball, R., Robin, A., \& Wu, J. S. (2003). Incentive versus standards: Properties of accounting income in four East Asian countries. Journal of Accounting and Economics, 36, 235-270. http://dx.doi.org/10.1016/j.jacceco.2003.10.003

Baydoun, N., \& Willett, R. (1995). Cultural relevance of Western accounting systems to developing countries. ABACUS, 31(1), 67-92. http://dx.doi.org/10.1111/j.1467-6281.1995.tb00355.x

Bedard, J., Chtourou, S. M., \& Courteau, L. (2004). The effects of audit committee expertise, independence and activity on aggressive earnings management. Auditing: A Journal of Practice \& Theory, 23(2), 13-35. http://dx.doi.org/10.2308/aud.2004.23.2.13

Bernard, V. L., \& Skinner, D. (1996). What motivates managers' choice of discretionary accruals? Journal of Accounting and Economics, 22(1-3), 313-325. http://dx.doi.org/10.1016/S0165-4101(96)00431-4

Chu, E. Y., \& Cheah, K. G. (2006). Does ownership structure matter? Evidence from Malaysian equity market. Corporate Ownership and Control, 4(1), 77-90.

Cohen, J. R., Pant, L. W., \& Sharp, D. J. (1993). Culture-based ethical conflicts confronting multinational accounting firms. Accounting Horizons, 7(3), 1-13.

Cornelius, P. (2005). Good corporate practices in poor corporate governance systems. Corporate Governance, 5(3), 12-23. http://dx.doi.org/10.1108/14720700510604661

Davidson, R., Goodwin-Stewart, J., \& Kent, P. (2005). Internal governance structures and earnings management. Accounting and Finance, 1-27.

Dechow, P. M., \& Dichev, I. D. (2002). The quality of accruals and earnings: The role of accrual estimation errors. The Accounting Review, Supplement, (77), 35-59.

DeFond, M., Hung, M., \& Trezevant, R. (2007). Investor protection and the information content of annual earnings announcements: International evidence. Journal of Accounting and Economics, 43, 37-67. 
http://dx.doi.org/10.1016/j.jacceco.2006.09.001

Flamholtz, E. (2001). Corporate culture and the bottom line. European Management Journal, 19(3), 268-275. http://dx.doi.org/10.1016/S0263-2373(01)00023-8

Francis, J., LaFond, R., Olsson, P.M., \& Schipper, K. (2005). The market pricing of accrual quality. Journal of Accounting and Economics, 39(2), 295-327. http://dx.doi.org/10.1016/j.jacceco.2004.06.003

Gomez, E. T., \& Jomo, K. S. (1999). Malaysia's political economy: Politics, patronage and profits (2nd ed.). Cambridge: Cambridge University Press.

Gray, S. J. (1988). Towards a theory of cultural influences on the development of accounting systems internationally. ABACUS, 24(1), 1-15. http://dx.doi.org/10.1111/j.1467-6281.1988.tb00200.x

Guan, L., Pourjalali, H., Sengupta, P., \& Teruya, J. (2005). Effect of cultural environment on earnings manipulation: A five Asia-Pacific country analysis. Multinational Business Review, 13(2), 23-41. http://dx.doi.org/10.1108/1525383X200500007

Gul, F. A. (2006). Auditors' response to political connection and cronyism in Malaysia. Journal of Accounting Research, 44(5), 931-963. http://dx.doi.org/10.1111/j.1475-679X.2006.00220.x

Haniffa, R. M., \& Cooke, T. E. (2002). Culture, corporate governance and disclosure in Malaysian corporations. ABACUS, 38(3), 317-349. http://dx.doi.org/10.1111/1467-6281.00112

Haniffa, R. M., \& Cooke, T. E. (2005). The impact of culture and governance on corporate social responsibility. Journal of Accounting and Public Policy, 24, 391-430. http://dx.doi.org/10.1016/j.jaccpubpol.2005.06.001

Healy, P. M., \& Wahlen, J. M. (1999). A review of the earnings management literature and its implications for standard setting. Accounting Horizons, 13(14), 365-383. http://dx.doi.org/10.2308/acch.1999.13.4.365

Hofstede, G. (1980). Culture's consequences: International differences in work-related values. Newbury Park, CA: Sage.

Hofstede, G. (1983). National cultures in four dimensions: A research theory of cultural differences among nations. International Studies of Management and Organization, XIII(1-2), 15-41.

Hope, O. K. (2003). Firm-level disclosures and the relatives roles of culture and legal origin. Journal of International Financial Management and Accounting, 14(3), 218-248. http://dx.doi.org/10.1111/1467-646X.00097

Jaggi, B., Leung, S., \& Gul, F. A. (2007). Board independence and earnings management in Hong Kong firms: Some evidence on the role of family ownership and family board control. Working Paper, Department of Accounting and Information System, Rutgers University.

Jaggi, B., Leung, S., \& Gul, F. A. (2009). Family control, board independence, and earnings management: Evidence based on Hong Kong firms. Journal of Accounting and Public Policy, 28(4), 281-300. http://dx.doi.org/10.1016/j.jaccpubpol.2009.06.002

Johnson, S., \& Mitton, T. (2003). Cronyism and capital controls: Evidence from Malaysia. Journal of Financial Economics, 67, 351-382. http://dx.doi.org/10.1016/S0304-405X(02)00255-6

Mamman, A. (2002). Managerial views on government intervention in Malaysia: The relevance of ethnic and employment backgrounds. Asia Pacific Business Review, 9(1), 1-20. http://dx.doi.org/10.1080/713999170

Mansor, N., \& Kennedy, J. (2000). Malaysian culture and the leadership of organizations: A globe study. Malaysian Management Review, 35(2).

Ow-Yong, K., \& Guan, C. K. (2000). Corporate governance codes: A comparison between Malaysia and the UK. Conference Papers, 8(2), 125-132.

Peasnell, K. V., Pope, P. F., \& Young, S. (2000). Accrual management to meet earnings targets: UK evidence pre and post Cadbury. British Accounting Review, 32, 415-445. http://dx.doi.org/10.1006/bare.2000.0134

Peasnell, K. V., Pope, P. F., \& Young, S. (2005). Board monitoring and earnings management: Do outside directors influence abnormal accruals? Journal of Business Finance \& Accounting, 32(7-8), 1311-1346. http://dx.doi.org/10.1111/j.0306-686X.2005.00630.x

Penman, S. H., \& Zhang, X. (2002). Accounting conservatism, the quality of earnings and stock returns. The Accounting Review, 77(2), 237-264. http://dx.doi.org/10.2308/accr.2002.77.2.237 
Salleh, Z., Stewart, J., \& Manson, S. (2006). The impact of board composition and ethnicity on audit quality: Evidence from Malaysian companies. Malaysian Accounting Review, 5(2), 61-83.

Tam, O. K., \& Tan, M. G. (2007). Ownership, governance and firm performance in Malaysia. Corporate Governance, 15(1), 208-222. http://dx.doi.org/10.1111/j.1467-8683.2007.00555.x

Tsakumis, G. (2007). The influence of culture on accountants' application of financial reporting rules. ABACUS, 43(1), 27-48. http://dx.doi.org/10.1111/j.1467-6281.2007.00216.x

Wah, S. S. (2002). Chinese classical leadership revisited: Lessons for the contemporary leader. Malaysian Management Review, 37(1), 11-18.

Weidenbaum, M., \& Hughes, S. (1996). The Bamboo Network. New York : The Free Press.

Yatim, P., Kent, P., \& Clarkson, P. (2006). Governance structures, ethnicity and audit fees of Malaysian listed firms. Managerial Auditing Journal, 21(7), 757-782. http://dx.doi.org/10.1108/02686900610680530 